\author{
Dariusz Filip \\ Uniwersytet Kardynała Stefana Wyszyńskiego w Warszawie \\ e-mail: d.filip@uksw.edu.pl
}

\title{
DOBÓR WALORÓW ORAZ WYCZUCIE RYNKU - UMIEJĘTNOŚCI ZARZĄDZAJĄCYCH FUNDUSZAMI INWESTYCYJNYMI*
}

\section{STOCK SELECTION AND MARKET TIMING: SKILLS OF MUTUAL FUND MANAGERS}

DOI: $10.15611 /$ pn.2018.531.09

JEL Classification: G11, G14, G23

\begin{abstract}
Streszczenie: Artykuł koncentruje się na ocenie umiejętności zarządzających portfelami inwestycyjnymi polskich funduszy akcyjnych. W badaniu wykorzystano stosunkowo dużą próbę badawczą, liczącą 87 podmiotów. Horyzont czasowy badania ustalono na okres 2000-2015. Wyniki menedżerów oceniane były pod kątem umiejętności doboru walorów oraz wyczucia rynku. Otrzymane rezultaty wskazują na brak umiejętności w przewidywaniu tendencji rynkowych, mierzonych parametrami z modeli Treynora-Mazuya oraz Henrikssona-Mertona. Analiza z wykorzystaniem testu istotności dla wartości średniej, liczebności dodatnich i ujemnych wyników, jak również metod panelowych dla danych przestrzenno-czasowych nie dała jednoznacznych rezultatów co do istnienia umiejętności selekcji.
\end{abstract}

Słowa kluczowe: umiejętności menedżerskie, efektywność, dobór walorów, wyczucie rynku.

Summary: This paper focuses on evaluating the skills of portfolio managers of Polish equity funds. A relatively large study sample, i.e. 87 entities, is used. The time horizon is the period 2000-2015. The returns are analyzed from the angle of stock selection and market timing ability. The obtained results show the lack of market timing skills measured with the parameters of Treynor-Mazuy and Henriksson-Merton models. The one sample $t$-test and frequency analysis of the positive and negative performance as well as the panel methods for the TSCS data are unequivocal in relation to the existence of stock selection skills.

Keywords: managerial skills, efficiency, stock selection, market timing.

* Tekst powstał w ramach projektu badawczego, który został sfinansowany ze środków Narodowego Centrum Nauki przyznanych na podstawie decyzji numer DEC-2014/15/D/HS4/01227. 


\section{Wstęp}

Hipoteza rynku efektywnego zakłada, że rynki finansowe bardzo dokładnie i w sposób sprawny odzwierciedlają dostępne publicznie informacje. Ponadto żadne strategie obrotu opierające się na przeszłych cenach instrumentów finansowych nie są w stanie dostarczyć ponadprzeciętnych dochodów [Jajuga, Jajuga 2007]. Przyjmuje się również, że na rynku nie istnieją inwestorzy posiadający dostęp do poufnych informacji pozwalających na osiąganie ponadprzeciętnych wyników, a sama informacja jest towarem, którego uzyskanie wymaga umiejętności czytania m.in. raportów finansowych (por. [Dębski 2012]). Przeciwstawna do ww. hipotezy jest teoria kapitału ludzkiego, zgodnie z którą zarządzający portfelami inwestycyjnymi mogą wykazywać się umiejętnością gromadzenia, przetwarzania i wykorzystania danych, z którymi nie byli w stanie właściwie zapoznać się pozostali inwestorzy. Pozwala to na osiągnięcie przewagi konkurencyjnej wybranych uczestników rynkowych.

Wśród inwestorów, którzy mogą cechować się takimi umiejętnościami, są menedżerowie zatrudnieni $\mathrm{w}$ instytucjach profesjonalnie zajmujących się inwestowaniem powierzonych środków, czyli m.in. funduszach inwestycyjnych. Zdolności inwestycyjne zarządzających powinny przekładać się na osiągane wyniki ważone ryzykiem, najlepiej jeśli uwzględniają one możliwość wystąpienia zmiany w czasie poziomu ryzyka systematycznego. Literatura przedmiotu wypracowała termin anormalnej stopy zwrotu, która może mieć różne źródła. Wymienia się tutaj umiejętności zarządzających w obszarze selekcji składników portfela oraz wykorzystania informacji o tendencjach rynkowych.

Celem pracy jest przeprowadzenie oceny efektywności funduszy inwestycyjnych, w kontekście zbadania umiejętności ich zarządzających w doborze walorów oraz wyczucia rynku. Generalnie, istotne będzie pokazanie, czy zarządzający funduszami inwestycyjnymi charakteryzują się zróżnicowanymi umiejętnościami menedżerskimi. Analiza wyników instytucji zbiorowego inwestowania jest szczególnie istotna z perspektywy weryfikacji hipotezy rynku efektywnego. Ponadto omawiana tematyka niesie ze sobą walory użytkowe. Dostarczenie dowodów świadczących o istnieniu ww. umiejętności może wpływać na decyzje inwestycyjne inwestorów indywidualnych, podpowiadając o ewentualnym potencjale skutecznego zarządzania powierzonymi środkami. Również same fundusze inwestycyjne mogą powielać informacje o posiadaniu właściwych umiejętności przez ich zarządzających w przekazach medialnych w celu zdobycia nowych klientów.

Przedkładany artykuł zbudowany jest z pięciu części. W części drugiej zaprezentowany zostanie krótki przegląd głównych prac w obszarze umiejętności zarządzających funduszami inwestycyjnymi, dokonany głównie w oparciu o badania pochodzące z krajowego rynku. Część trzecia, będąca sekcją metodyczną, zawiera zestawienie wykorzystanych narzędzi w ocenie selekcji oraz wyczucia rynkowego, jak również zastosowanych podejść badawczych. W części czwartej raportuje się 
empiryczne ustalenia. Natomiast część ostatnia scala najważniejsze rezultaty prezentowanego badania.

\section{Przegląd literatury}

Jednym z najważniejszych modeli rynku kapitałowego jest CAPM. Za twórców tego modelu uważa się Sharpe'a [1964], Lintnera [1965] i Mossina [1966]. Jednak dopiero uwzględnienie pierwszych czynników rynkowych (np. [Jensen 1968]) oraz dokonywanie modyfikacji ${ }^{1}$ miary selektywności w celu umożliwienia oceny wykorzystywania przez menedżerów ruchów rynkowych pozwoliły na wypracowanie zestawu narzędzi ewaluacji umiejętności menedżerskich (np. [Bhattachary, Pfleiderer 1993; Grinblatt, Titman 1989; Connor, Korajczyk 1991]). Jednak wraz ze wzbogacaniem oferty produktowej, szczególnie w krajach rozwiniętych, oraz przyśpieszeniem w dotarciu do informacji, spowodowanym rozwojem technologii, ale jednocześnie funkcjonowaniem rynków silnie zależnych od kryzysów finansowych, trudno o stabilne w czasie rezultaty inwestycyjne, które byłyby efektem posiadania umiejętności doboru składników do portfela oraz identyfikacji trendów rynkowych. A zatem hipoteza rynku efektywnego wydaje się wciąż niewzruszona.

$\mathrm{W}$ ramach omawiania literatury przedmiotu, poświęconej efektywności polskich funduszy inwestycyjnych wynikającej z umiejętności zarządzających, zestawione zostaną opracowania, w których oprócz ocen umiejętności selekcji walorów do portfela koncentrowano się na kwestii czasu reakcji na informację rynkową. Jedną z pierwszych kompleksowych analiz w Polsce, zajmujących się efektownością rynków, była praca Czekaja, Wosia oraz Żarnowskiego [2001]. Wykorzystując zarówno narzędzia w ocenie selektywności (wskaźnik Sharpe’a, alfa Sharpe’a, wskaźnik Treynora, alfa Jensena), jak i wyczucia rynku (miary Treynora-Mazuya oraz Henrikssona-Mertona) dla 29 funduszy mających w swoich portfelach akcje polskich spółek, pokazali oni dla horyzontu 1999-2000, że nie ma podstaw do odrzucenia hipotezy efektywności silnej.

Wśród bardziej współczesnych prac można wymienić chociażby analizę Włodarczyk i Skrodzkiej [2013], które zajęły się oceną efektywności zarządzania 9 portfelami polskich funduszy akcyjnych w okresie 2005-2012. Elementem wyróżniającym wymienione opracowanie jest zastosowanie modelu Treynora-Mazuya przełączanego łańcuchem Markowa. Uzyskane rezultaty nie pozwalały jednak w sposób jednoznaczny dokonać oceny efektywności zarządzania portfelami funduszy, w tym zdolności selekcji poszczególnych zarządzających. Również Pietrzyk [2014] ostrożnie interpretował otrzymane rezultaty. Porównywał on efekty zarządzania 8 funduszami zrównoważonymi w odniesieniu do portfeli wzorcowych. Wykorzystanymi miarami umiejętności menedżerskich były modele Treynora-Mazuya, Henrikssona-Mertona, Connora-Korajczyka oraz dwuczynnikowy

1 Więcej na temat miar selektywności oraz identyfikacji trendów rynkowych zob. Borowski [2014]. 
model (uwzględniający dwa wskaźniki rynku, tj. akcji i obligacji). Horyzont badania ustalono na okres styczeń 2001 - sierpień 2013. Otrzymane rezultaty wskazują na brak osiągania ponadprzeciętnych wyników przez analizowane podmioty z tytułu przewidywania i wykorzystywania ruchów rynkowych. Z kolei Witkowska, Kompa i Grabska [2009] badali efektywność 19 funduszy zrównoważonych i aktywnej alokacji w okresie listopad 2006 - listopad 2008. Cechą wyróżniającą omawianą pracę było użycie 3-, 6-, 12- oraz 24-miesięcznych szeregów czasowych. Na podstawie tradycyjnych miar (wskaźniki Sharpe’a, Treynora oraz alfy Jensena), ale i narzędzi do oceny selektywności i wyczucia rynku (modele Treynora-Mazuya oraz Henrikssona-Mertona) ustalono, że fundusze zrównoważone, jak i aktywnej alokacji nie były zarządzane w sposób efektywny. Jednocześnie wspomniani autorzy zauważają, że otrzymane rezultaty z wykorzystaniem różnych sposobów oceny nie były jednoznaczne.

Istnieją jednak prace znacznie bardziej wymownie odnoszące się do umiejętności polskich zarządzających w obszarze selekcji i wyczucia rynkowego. Przykładowo, Węgrzyn [2015] analizował umiejętności zarządzających 5 funduszami prowadzącymi aktywną politykę inwestycyjną w okresie 2009-2013. Ocena efektywności dokonana była przy wykorzystaniu modelu Treynora-Mazuya oraz Henrikssona-Mertona. Poczynione ustalenia wskazują na to, iż w większości przypadków wartości parametrów modeli nie pozwalały na potwierdzenie umiejętności przewidywania przyszłej koniunktury giełdowej przez zarządzających funduszami. Co więcej, część analizowanych funduszy nie była w stanie dostarczyć swoim klientom stóp zwrotu pozwalających pokryć opłatę za zarządzanie. Również Żelazowska [2017] zajęła się zagadnieniem wyczucia rynku oraz odpowiedniej selekcji walorów do portfela wśród trzech funduszy w okresie listopad 2013 - październik 2016. Wykorzystując model Henrikssona-Mertona, ustaliła, że menedżerowie funduszy nie mają umiejętności w zakresie wyczucia rynku, jak i selektywności.

Z kolei Zamojska [2012] analizowała przydatność i trafność modeli wyceny aktywów w celu dokonania oceny efektywności zarządzania 13 funduszami akcji. Przeprowadzając analizę szeregów czasowych nadwyżek stóp funduszy, autorka skorzystała z miar wyników ustalanych w oparciu o warunkowe oraz bezwarunkowe modele CAPM, Treynora-Mazuya, Henrikssona-Mertona, CAPM uwzględniającego moment trzeciego rzędu, oraz liniowy model z czynnikami zbywalnymi i osobno z czynnikami niezbywalnymi. Na podstawie wyznaczonych bootstrapowych rozkładów dla parametru alfa i statystyki $t$ pokazano, że zarządzający osiągali nadzwyczajne wyniki inwestycyjne na skutek szczęśliwego zbiegu okoliczności.

Również Olbryś [2010] dokonała oceny efektywności zarządzania 15 polskimi funduszami akcji działającymi w okresie 2003-2009, z wykorzystaniem wieloczynnikowych modeli market-timing. Jako miar wyników użyto modeli Treynora-Mazuya oraz Henrikssona-Mertona, rozszerzonych o czynniki Famy i Frencha, czyli portfele naśladujące wielkość ( $S M B)$ oraz wartość spółek $(H M L)$, jak również nową zmienną, tzw. wartość dodaną. Otrzymane rezultaty nie potwierdziły istnienia 
umiejętności zarządzających portfelami tych funduszy w zakresie wyczucia rynku oraz selektywności aktywów. Podobnie Homa i Mościbrodzka [2016] podjęły próbę zbadania wpływu opóźnionych czynników w modelu trójczynnikowym Famy-Frencha z uwzględnieniem parametrów pozwalających na pomiar umiejętności wyczucia rynku, pochodzących z klasycznych modeli Treynora-Mazuya oraz Henrikssona-Mertona. Badaniem objęto 67 funduszy akcji funkcjonujących w okresie od stycznia 2009 do czerwca 2015 roku. W wyniku przeprowadzonej analizy wspomniane autorki zauważyły konieczność zastępowania klasycznych parametrów trójczynnikowego modelu hybrydowego, z elementami strategii market timing, przez ich opóźnione w czasie odpowiedniki, które mogą odzwierciedlać rzeczywiste ryzyko systematyczne i efektywność funduszy.

Pietrzyk [2013] z kolei analizował wyniki 8 polskich funduszy akcji w okresie 2000-2011. W celu oceny ich efektywności w obszarze doboru papierów wartościowych do portfela oraz wyczucia trendów rynkowych posłużył się modelem Bhattachary'ego-Pfleiderera. W wyniku przeprowadzonej analizy ustalono, że w zasadzie zarządzający funduszami nie mają umiejętności osiągania wyższych stóp zwrotu z tytułu doboru walorów oraz wyczucia rynku. Co więcej, zaobserwowano negatywne zdolności zarządzających z tytułu prognozowania i wykorzystywania trendów rynkowych.

Ogólnie, pomimo podejmowania dość licznych prób oceny zarządzania funduszami inwestycyjnymi, otrzymywane ustalenia w polskiej literaturze wciąż nie są jednoznaczne (por. [Miziołek, Trzebiński 2017]). Wydłużenie okresu badawczego oraz znaczne zwiększenie zakresu podmiotowego pozwolą na przeprowadzenie badania efektywności przy ograniczonym efekcie doboru próby, który mógł do tej pory wpływać na poczynione ustalenia.

\section{Charakterystyka podejścia badawczego oraz materiału empirycznego}

W ramach mierników oceny posiadania przez zarządzających portfelami inwestycyjnymi umiejętności menedżerskich wymienia się narzędzia do przewidywania rynku w skali mikro oraz makro. Pierwsze z nich związane są z umiejętnością doboru papierów wartościowych (stock selection), drugie zaś - umiejętnością wyczucia rynku (market timing). W niniejszym badaniu wykorzystane zostaną najpopularniejsze metody oceny efektów alokacji aktywów związane z pomiarem tych umiejętności.

Wśród tradycyjnych metod ewaluacji umiejętności zarządzających można wymienić podejście przedstawione przez Treynora i Mazuya, uwzględniające paraboliczne zakrzywienie linii charakterystycznej portfela. W konstrukcji wymienionego podejścia skorzystano z założeń modelu CAPM. Ostatecznie model Treynora-Mazuya [1966] przyjmuje następującą postać: 


$$
r_{i, t}-r_{f . t}=\alpha_{i}+\beta_{i}\left(r_{m, t}-r_{f, t}\right)+\gamma_{i}\left(r_{m, t}-r_{f, t}\right)^{2}+\varepsilon_{t},
$$

gdzie: $\alpha_{i}$ oznacza wyraz wolny reprezentujący umiejętność selekcji aktywów; $\beta_{i}$ jest stałą częścią odzwierciedlającą ryzyko systematyczne $i$-tego funduszu w okresie $t$, wynikające z samej specyfiki inwestycji w instrumenty finansowe; zaś $\gamma_{i}$ jest zmienną częścią współczynnika beta, odzwierciedlającą podejmowane działania manipulacyjne przez zarządzającego w celu właściwej realizacji strategii, polegającej na identyfikacji trendów rynkowych. Pozostałe elementy równania pochodzą ze wspomnianego klasycznego modelu wyceny aktywów kapitałowych, tj.: $r_{i, t}$ jest stopą zwrotu uzyskaną w okresie $t$ przez fundusz $i ; r_{f, t}$ stanowi stopę zwrotu wolną od ryzyka; $r_{m, t}$ oznacza stopę zwrotu z portfela rynkowego; zaś $\varepsilon_{t}$ jest składnikiem losowym.

Drugim klasycznym modelem do pomiaru umiejętności menedżerskich jest podejście zaproponowane przez Henrikssona i Mertona. Umożliwia ono identyfikację oraz ocenę umiejętności zarządzającego portfelem inwestycyjnym w zakresie wykorzystania trendów rynkowych, jak również doboru papierów wartościowych. W ramach omawianego podejścia znajduje się sztuczna zmienna $D$, zależna od sytuacji rynkowej. W przypadku tego modelu umiejętność przewidywania tendencji rynkowych polega na zwiększaniu ekspozycji na ryzyko (zwiększanie wartości współczynnika beta) w okresie lepszej koniunktury rynkowej i zmniejszaniu ryzyka (obniżanie wartości współczynnika beta) w okresie gorszej koniunktury. Parametryczny model Henrikssona-Mertona [1981] przyjmuje następującą postać:

$$
r_{i, t}-r_{f . t}=\alpha_{i}+\beta_{i}\left(r_{m, t}-r_{f, t}\right)+\theta_{i}\left[\left(r_{m, t}-r_{f, t}\right) D\right]+\varepsilon_{t},
$$

gdzie: $\theta_{i}$ jest parametrem związanym z wyczuciem rynkowym (stosowaniem techniki market timing) zarządzającego funduszem $i$, z kolei $D$ interpretujemy jako:

$$
D=\left\{\begin{array}{l}
1, r_{m, t}>r_{f, t} \\
0, r_{m, t} \leq r_{f, t}
\end{array} .\right.
$$

Sytuacja rynkowa wyrażona przez zmienną $D$ może być odczytana jako powtórzona w modelu wartość ryzyka systematycznego $i$-tego funduszu w okresie $t$, w którym dochodowość indeksu rynkowego była wyższa niż stopa wolna od ryzyka. W okresach kiedy stopa zwrotu z indeksu nie przewyższała dochodowości inwestycji bez ryzyka, wartość omawianego wyrażenia wynosiła 0. Oznacza to, że dodatnia wartość parametru $\theta_{i}$ może stanowić o wyczuciu rynkowym w postaci zwiększenia zaangażowania w bardziej ryzykowne papiery wartościowe, w momencie kiedy indeks rynkowy zyskiwał na wartości, oraz zmniejszenia zaangażowania - kiedy indeks tracił na wartości. 
Na podstawie estymacji wymienionych modeli metodą najmniejszych kwadratów otrzymano wartości współczynników traktujących o posiadanych przez zarządzających umiejętnościach. Obserwacje pozwalające na obliczenie parametrów wspomnianych modeli miały charakter miesięczny, zaś analizowane miary umiejętności menedżerskich kalkulowane były w ujęciu rocznym. Wykorzystanymi benchmarkami były: indeks WIG jako portfel rynkowy oraz rentowność 7-dniowych bonów pieniężnych jako stopa wolna od ryzyka.

Analizą objęto 87 zarejestrowanych krajowych funduszy akcji, funkcjonujących w okresie 2000-2015. Dane, które były przedmiotem badania (w postaci wartości jednostek uczestnictwa), pochodziły z raportów niepublicznej agencji Analizy Online. Warta odnotowania jest informacja o liczbie funduszy w poszczególnych latach badania. W pierwszym roku analizy było ich 10, w 2005 roku - 18, a w roku 2010 już 49. W związku z powyższym próba badawcza obarczona była błędem przetrwania. Jednak jak pokazują dotychczasowe badania (zob. [Perez 2011]), siła i wielkość efektu związanego z nieuwzględnianiem podmiotów, które zostały wycofane z ryn$\mathrm{ku}$, były jeszcze do niedawna niewielkie.

Procedura badawcza realizowana w niniejszym opracowaniu składać się będzie $z$ trzech narzędzi. W pierwszej kolejności przeprowadzony zostanie klasyczny test istotności dla jednej średniej w populacji. Następnie zostanie przeprowadzona analiza dla danych przekrojowych w kolejnych latach horyzontu badania, z wyszczególnieniem liczebności podmiotów charakteryzujących się umiejętnościami w doborze walorów, jak również w obszarze wyczucia tendencji rynkowych. Ostatnim krokiem będzie badanie panelowe. Weryfikowane hipotezy badawcze można rozpisać w szczegółowy sposób:

\begin{tabular}{|c|c|c|c|}
\hline $\begin{array}{c}\text { Umiejętność } \\
\text { selekcji walorów } \\
\text { na podstawie modelu } \\
\text { Treynor-Mazuy }\end{array}$ & $\begin{array}{c}\text { Umiejętność } \\
\text { selekcji walorów } \\
\text { na podstawie modelu } \\
\text { Henriksson-Merton }\end{array}$ & $\begin{array}{c}\text { Umiejętność } \\
\text { wyczucia rynku } \\
\text { na podstawie modelu } \\
\text { Treynor-Mazuy }\end{array}$ & $\begin{array}{c}\text { Umiejętność } \\
\text { wyczucia rynku } \\
\text { na podstawie modelu } \\
\text { Henriksson-Merton }\end{array}$ \\
\hline $\mathrm{H}_{0}: \alpha=0$ & $\mathrm{H}_{0}: \alpha=0$ & $\mathrm{H}_{0}: \gamma=0$ & $\mathrm{H}_{0}: \theta=0$ \\
\hline $\mathrm{H}_{1}: \alpha \neq 0$ & $\mathrm{H}_{1}: \alpha \neq 0$ & $\mathrm{H}_{0}: \gamma \neq 0$ & $\mathrm{H}_{0}: \theta \neq 0$ \\
\hline
\end{tabular}

W ramach pierwszego podejścia badawczego przyjmuje się zestaw następujących hipotez:

- przeciętna anormalna stopa zwrotu funduszy inwestycyjnych, wyrażona poprzez umiejętność doboru papierów wartościowych do portfela ( $\alpha$ z modelu TreynoraMazuya oraz Henrikssona-Mertona), nie różni się istotnie od 0 - a zatem zarządzający funduszami nie posiadają umiejętności selekcji walorów pozwalających osiągać ponadprzeciętne wyniki;

- przeciętna wrażliwość zarządzających funduszami inwestycyjnymi na trendy rynkowe, wyrażona miarą identyfikacji i wykorzystania ruchów rynkowych $(\gamma \operatorname{oraz} \theta)$, nie różni się istotnie od 0 - a zatem zarządzający portfelami nie posiadają umiejętności stosowania strategii market timing. 
Umiejętności selekcji oraz wyczucia rynku testowane będą statystyką $t$-Studenta dla jednej próby według następującego wzoru:

$$
t=\frac{\mu}{S} \sqrt{n}_{t},
$$

gdzie: $t$ jest to wartość testu $t$-Studenta; $\mu$ oznacza wartość średniej w próbie; $S$ oznacza wartość odchylenia standardowego w próbie; zaś $n$ to liczba obserwacji. Standardowo przyjęto poziom istotności wynoszący 0,05 .

Drugie z narzędzi badawczych pozwoli jedynie na pośrednie odniesienie się do hipotezy o istnieniu umiejętności menedżerskich. Zastosowana procedura polegać będzie na zliczaniu dodatnich oraz ujemnych rocznych wskaźników w postaci dodatkowych stóp zwrotu z tytułu aktywnego zarządzania portfelem instrumentów finansowych, jak również efektów wykorzystania ruchów rynkowych. Dodatkowo zdecydowano się zliczać parametry uzyskane w wyniku estymacji modeli (1) oraz (2), których wartości były statystycznie istotne. Czynności te powtórzono dla całego horyzontu badania. Analiza ta pozwoli odpowiedzieć na pytanie o częstość występowania dodatkowych korzyści z tytułu wykorzystania ruchów rynkowych, których efektem mogą być właśnie ponadprzeciętne wyniki inwestycyjne.

Trzecia z wykorzystanych metod związana jest z użyciem danych o charakterze przestrzenno-czasowym. Na ich podstawie przeprowadzono badanie panelowe, w którym to estymowano parametry poszczególnych modeli za pomocą regresji z efektami ustalonymi. Metody panelowe bazowały na modelach opisanych w badaniu jako (1) oraz (2). Weryfikowana hipoteza zerowa w tym przypadku zakładała, że zarządzający funduszami, poprzez dobór walorów do portfela, nie są w stanie dostarczać swoim klientom ponadprzeciętnych wyników inwestycyjnych, a więc wyestymowany parametr $\alpha$ będzie równy zeru. Ponadto założono brak efektów związanych ze stosowaniem strategii polegającej na właściwej identyfikacji trendów rynkowych, a zatem wartości kolejnych regresorów będą wynosiły zero. Statystyczna istotność współczynników regresji oraz wyrazu wolnego będzie weryfikowana testem $t$. W przypadku gdy obliczona wartość statystyki testowej jest większa co do modułu od wartości krytycznej odczytanej z tablic rozkładu $t$-Studenta dla danego poziomu istotności, da to podstawy do odrzucenia hipotezy zerowej. Znak parametrów regresji w przypadku ich statystycznej istotności będzie informował o umiejętnym lub też nieumiejętnym zarządzaniu portfelem.

\section{Otrzymane wyniki}

Jak wspomniano wcześniej, do zweryfikowania postawionych hipotez wykorzystano kilka podejść badawczych. Różnorodność wykorzystanych narzędzi analizy pozwoli na zwiększenie stopnia pewności we wnioskowaniu statystycznym. Omówie- 
nie rezultatów badawczych rozpoczynają ustalenia pochodzące z analizy istotności średniej dla pojedynczej próby (zob. tabela 1).

Tabela 1. Testowanie istotności średnich wyników w próbie

\begin{tabular}{|l|c|c|c|r|}
\hline \multirow{2}{*}{} & \multicolumn{2}{|c|}{ Treynor-Mazuy } & \multicolumn{2}{c|}{ Henriksson-Merton } \\
\cline { 2 - 5 } & $\alpha$ & $\gamma$ & $\alpha$ & \multicolumn{1}{c|}{$\theta$} \\
\hline Statystyka $t$ & 0,6631 & $-6,9864$ & 4,2079 & $-9,0456$ \\
\hline$p$-value & 0,5075 & 0,0000 & 0,0000 & 0,0000 \\
\hline Różnica średnich & 0,0003 & $-1,1200$ & 0,0021 & $-0,2409$ \\
\hline Dolna granica (95\% przedział ufności) & $-0,0006$ & $-1,4348$ & 0,0011 & $-0,2932$ \\
\hline Górna granica (95\% przedział ufności) & 0,0011 & $-0,8052$ & 0,0031 & $-0,1886$ \\
\hline
\end{tabular}

Źródło: opracowanie własne.

Tabela 2. Zestawienie częstości występowania dodatnich oraz ujemnych wartości parametrów modeli w latach 2000-2015

\begin{tabular}{|r|r|r|r|r|r|r|r|r|}
\hline \multirow{2}{*}{ Rok } & \multicolumn{4}{|c|}{ Treynor-Mazuy } & \multicolumn{4}{|c|}{ Henriksson-Merton } \\
\cline { 2 - 9 } & \multicolumn{2}{|c|}{$\alpha$} & \multicolumn{2}{|c|}{$\alpha$} & \multicolumn{2}{|c|}{$\theta$} \\
\cline { 2 - 9 } & dodatnie & \multicolumn{1}{|c|}{ ujemne } & dodatnie & ujemne & dodatnie & ujemne & dodatnie & ujemne \\
\hline 2000 & $7(4)$ & $3(0)$ & $5(2)$ & $5(3)$ & $7(3)$ & $3(0)$ & $5(2)$ & $5(3)$ \\
\hline 2001 & $3(0)$ & $8(2)$ & $11(2)$ & $0(0)$ & $3(0)$ & $8(1)$ & $11(3)$ & $0(0)$ \\
\hline 2002 & $9(0)$ & $3(1)$ & $2(0)$ & $10(5)$ & $10(1)$ & $2(1)$ & $2(0)$ & $10(4)$ \\
\hline 2003 & $10(3)$ & $5(0)$ & $9(1)$ & $6(1)$ & $6(1)$ & $9(0)$ & $11(1)$ & $4(1)$ \\
\hline 2004 & $13(1)$ & $3(0)$ & $3(0)$ & $13(1)$ & $12(0)$ & $4(0)$ & $7(0)$ & $9(0)$ \\
\hline 2005 & $6(1)$ & $12(3)$ & $7(0)$ & $11(2)$ & $8(2)$ & $10(1)$ & $7(0)$ & $11(2)$ \\
\hline 2006 & $19(5)$ & $3(0)$ & $14(3)$ & $8(1)$ & $13(3)$ & $9(0)$ & $15(2)$ & $7(0)$ \\
\hline 2007 & $16(1)$ & $14(0)$ & $15(0)$ & $15(2)$ & $16(1)$ & $14(0)$ & $16(0)$ & $14(1)$ \\
\hline 2008 & $7(0)$ & $35(19)$ & $7(0)$ & $35(9)$ & $13(1)$ & $29(5)$ & $4(0)$ & $38(9)$ \\
\hline 2009 & $25(1)$ & $23(0)$ & $21(0)$ & $27(5)$ & $26(1)$ & $22(0)$ & $19(0)$ & $29(6)$ \\
\hline 2010 & $25(3)$ & $24(4)$ & $27(4)$ & $22(2)$ & $22(4)$ & $27(3)$ & $23(4)$ & $26(3)$ \\
\hline 2011 & $6(0)$ & $53(14)$ & $18(2)$ & $41(5)$ & $15(0)$ & $44(7)$ & $17(2)$ & $42(6)$ \\
\hline 2012 & $27(0)$ & $36(7)$ & $16(1)$ & $47(1)$ & $40(0)$ & $23(4)$ & $14(1)$ & $49(4)$ \\
\hline 2013 & $55(10)$ & $21(2)$ & $49(1)$ & $27(0)$ & $58(3)$ & $18(0)$ & $49(2)$ & $27(2)$ \\
\hline 2014 & $21(1)$ & $58(13)$ & $28(1)$ & $51(4)$ & $25(2)$ & $54(6)$ & $28(1)$ & $51(4)$ \\
\hline 2015 & $68(34)$ & $15(2)$ & $11(1)$ & $72(14)$ & $70(38)$ & $13(2)$ & $8(1)$ & $75(24)$ \\
\hline Razem & $317(64)$ & $316(67)$ & $243(18)$ & $390(55)$ & $344(60)$ & $289(30)$ & $236(19)$ & $397(69)$ \\
\hline
\end{tabular}

Źródło: opracowanie własne.

W tabeli 1 przedstawiono rezultaty badania istotności średniej testem $t$-Studenta. Jak wynika z przeprowadzonej analizy, otrzymane rezultaty, dotyczące umiejętności doboru walorów do portfela, nie są jednoznaczne. Średnie wyniki w próbie mierzone alfą z modelu Treynora-Mazuya nie różnią się istotnie od zera, co też oznacza, że zarządzający posiadają przeciętne umiejętności w doborze walorów do portfela. Z kolei średnia wartość wyrazów wolnych w modelu Henrikssona- 
-Mertona znacząco przewyższa wartość zadaną. Oznacza to, iż według drugiego z wykorzystanych modeli polscy zarządzający posiadają umiejętność doboru papierów wartościowych, która może być powiązaną z pewną wrażliwością na trendy rynkowe. Ocena samej umiejętności przewidywania tendencji rynkowych przez zarządzających w tym przypadku jest już bardziej jednoznaczna. Średnie wartości parametrów $\gamma$ oraz $\theta$ istotnie różnią się od zera, a ich znak jest ujemny, co też pokazuje, iż uzyskiwanie ewentualne lepszych wyników inwestycyjnych nie jest spowodowane właściwym wyczuciem rynkowym. Otrzymane rezultaty zasługują na dalsze wyjaśnienia. Tabela 2 zawiera informacje o liczbie dodatnich oraz ujemnych wyników, wraz z rozbiciem na liczebności statystycznie istotnych parametrów (w nawiasach).

Zestawienie rocznej liczebności szacowanych parametrów regresji jest kontynuacją badania umiejętności menedżerskich, niemniej jednak dostarcza ono jedynie pośrednich argumentów w ocenie zdolności zarządzania portfelem inwestycyjnym. Roczne obserwacje w poszczególnych okresach badania, jak i dla całego horyzontu analizy, dobrze korespondują z ustaleniami prezentowanymi poprzednio. $\mathrm{Z}$ dwóch zastosowanych narzędzi oceny umiejętności zarządzających jedynie dla wyrazów wolnych modelu Henrikssona-Mertona łączna liczba dodatnich wyników funduszy akcji przewyższała liczbę ujemnych rezultatów w całym okresie. Również możliwe było zaobserwowanie dominacji korzystnych dla klientów tych instytucji wyników w większości rocznych okresów. To spostrzeżenie dotyczy też liczebności statystycznie istotnych wartości parametru $\alpha$, w przeciwieństwie do wyrazów wolnych modelu Treynora-Mazuya, które były o zbliżonej częstości występowania. Liczba dodatnich wartości parametrów $\gamma$ oraz $\theta$, reprezentujących umiejętność wyczucia trendów rynkowych, była znacząco niższa niż rocznych wartości ujemnych, co też oznacza, że zarządzającym polskimi funduszami akcji trudno jest właściwie przewidywać koniunkturę rynkową. W tym przypadku otrzymane rezultaty są zgodnie dla modelu Treynora-Mazuya, jak i Henrikssona-Mertona. Należy jednak zauważyć, że jedynie ok. 12-20\% wszystkich estymowanych parametrów było statystycznie istotnych, a zatem ustalenia te należy traktować z pewną dozą ostrożności.

Warto również zwrócić uwagę na okresy, w których miały miejsce największe spadki na rynkach papierów wartościowych, szczególnie lata 2008 oraz 2010. Niezależnie od rozpatrywanego modelu, jak i analizowanego parametru odpowiadającego umiejętnościom menedżerskim, fundusze, które mogłyby odnotowywać zarówno dodatnie wyniki w doborze walorów, jak i wyczucia rynkowego, należały do rzadkości. W związku z powyższym uzasadnione wydaje się użycie kolejnego podejścia, w którym przeprowadzona analiza będzie dotyczyła anormalnych stóp zwrotu w ujęciu miesięcznym (tabela 3 ).

Rezultaty przedstawione w tabeli 3 dotyczą analizy regresji funduszy akcji działających w okresie 2000-2015 oraz czterech wyróżnionych podokresach. Dla przypomnienia, zerowa wartość parametrów $\alpha, \gamma$, oraz $\theta$ będzie oznaczała, że zarządzający posiadają przeciętne umiejętności sprawnego poszukiwania i przetwa- 
Dobór walorów oraz wyczucie rynku - umiejętności zarządzających funduszami...

Tabela 3. Analiza regresji wyników funduszy inwestycyjnych na podstawie miesięcznych danych o charakterze przestrzenno-czasowym

\begin{tabular}{|c|c|c|c|c|c|c|c|c|c|c|}
\hline \multicolumn{11}{|c|}{ Panel A: Treynor-Mazuy } \\
\hline & \multicolumn{2}{|c|}{ cały okres } & \multicolumn{2}{|c|}{$2000-2003$} & \multicolumn{2}{|c|}{$2004-2007$} & \multicolumn{2}{|c|}{$2008-2011$} & \multicolumn{2}{|c|}{$2012-2015$} \\
\hline \multirow[t]{2}{*}{$\alpha$} & 0,000430 & & 0,002876 & ** & 0,001783 & $* *$ & $-0,003172$ & $* * *$ & 0,001196 & ** \\
\hline & 0,000302 & & 0,001213 & & 0,000867 & & 0,000565 & & 0,000528 & \\
\hline \multirow[t]{2}{*}{$\beta$} & 0,842243 & $* * *$ & 0,749640 & $* * *$ & 0,870918 & **** & 0,865431 & $* * *$ & 0,804860 & $* * *$ \\
\hline & 0,004705 & & 0,012982 & & 0,012198 & & 0,006823 & & 0,010901 & \\
\hline \multirow[t]{2}{*}{$\gamma$} & $-0,290233$ & $* * *$ & $-0,274354$ & $*$ & $-0,076286$ & & $-0,183184$ & $* * *$ & $-0,121052$ & \\
\hline & 0,040280 & & 0,139876 & & 0,184013 & & 0,047631 & & 0,245419 & \\
\hline Obser. & 7969 & & 601 & & 1159 & & 2496 & & 3713 & \\
\hline Fundusze & 87 & & 15 & & 52 & & 62 & & 87 & \\
\hline$R$-kwadrat & 0,8051 & & 0,8638 & & 0,8300 & & 0,8744 & & 0,6398 & \\
\hline test $F$ & 369,8005 & $* * *$ & 231,4944 & $* * *$ & 126,5696 & $* * *$ & 268,8373 & $* * *$ & 73,1534 & $* * *$ \\
\hline \multicolumn{11}{|c|}{ Panel B: Henriksson-Merton } \\
\hline & \multicolumn{2}{|c|}{ cały okres } & \multicolumn{2}{|c|}{$2000-2003$} & \multicolumn{2}{|c|}{ 2004-2007 } & \multicolumn{2}{|c|}{$2008-2011$} & \multicolumn{2}{|c|}{$2012-2015$} \\
\hline \multirow[t]{2}{*}{$\alpha$} & 0,001234 & $* * *$ & 0,003200 & $*$ & 0,001461 & & $-0,002839$ & $* * *$ & 0,002797 & *** \\
\hline & 0,000417 & & 0,001651 & & 0,001223 & & 0,000719 & & 0,000751 & \\
\hline \multirow[t]{2}{*}{$\beta$} & 0,884810 & $* * *$ & 0,775406 & $* * *$ & 0,867831 & **** & 0,892335 & $* * *$ & 0,867611 & *** \\
\hline & 0,008619 & & 0,027625 & & 0,027197 & & 0,010981 & & 0,025501 & \\
\hline \multirow[t]{2}{*}{$\theta$} & $-0,081300$ & $* * *$ & $-0,060593$ & & 0,004049 & & $-0,050101$ & $* * *$ & $-0,110328$ & $* * *$ \\
\hline & 0,014493 & & 0,044293 & & 0,044261 & & 0,019440 & & 0,039890 & \\
\hline Obser. & 7969 & & 601 & & 1159 & & 2496 & & 3713 & \\
\hline \begin{tabular}{|l|} 
Fundusze \\
\end{tabular} & 87 & & 15 & & 52 & & 62 & & 87 & \\
\hline$R$-kwadrat & 0,8046 & & 0,8633 & & 0,8299 & & 0,8740 & & 0,6406 & \\
\hline test $F$ & 368,6161 & $* * *$ & 230,5937 & $* * *$ & 126,5472 & *** & 267,8134 & $* * *$ & 73,3870 & $* * *$ \\
\hline
\end{tabular}
0,10 .

Uwaga: *** istotność na poziomie 0,01 ; * istotność na poziomie 0,05 ; * istotność na poziomie

Źródło: opracowanie własne.

rzania informacji publicznych, a dobór walorów do portfela, jak i stosowanie strategii market timing opiera się na informacjach ogólnie dostępnych (por. [Perez 2012]). Pierwszy z omawianych współczynników, zarówno dla modelu Treynora-Mazuya, jak i Henrikssona-Mertona, nie może być jednoznacznie interpretowany. Różne okresy, w których dobór walorów, kalkulowany z wykorzystaniem zastosowanych modeli, okazywał się statystycznie istotny, a przede wszystkim różnice w znakach stojących przed samą wartością współczynnika skłaniają do kontynuowania analiz z wykorzystaniem innych podejść. Z kolei regresory, odczytywane w tym badaniu jako wskaźniki wyczucia rynku, w postaci parabolicznego zakrzywienia linii charakterystycznej portfela $(\gamma)$, jak i parametru powiązanego ze zmienną jakościową dla rynku zwyżkującego $(\theta)$, cechuje ujemna wartość. Oznacza to, że zarządzający nie byli w stanie właściwie przewidywać kształtowania się trendów rynkowych i na tej postawie dostosowywać składu portfela do tych zmian. Ponieważ wartości $p$ 
statystyki $t$-Studenta dla czynników ww. modeli są mniejsze od wartości przyjętych poziomów ufności, można odrzucić hipotezę zerową, mówiącą o braku wrażliwości zarządzających funduszami inwestycyjnymi na trendy rynkowe, na korzyść hipotezy alternatywnej, stanowiącej o istnieniu gorszych niż przeciętne rezultatów inwestycyjnych i jednoczesnym braku umiejętności doboru walorów do portfela oraz wyczucia trendów rynkowych. Tak jak wspomniano wcześniej, istnienie umiejętności doboru walorów do portfela nie mogło zostać w sposób jednoznaczny potwierdzone.

\section{Podsumowanie}

Celem pracy było przeprowadzenie oceny umiejętności menedżerów zarządzających portfelami polskich funduszy akcyjnych w obszarze doboru walorów oraz wyczucia rynku. W związku z pojawiającą się w literaturze przedmiotu wrażliwością uzyskanych rezultatów na zastosowane podejścia badawcze, uzasadnione było skorzystanie z kilku narzędzi analitycznych do oceny jakości zarządzania powierzonymi środkami. W niniejszej pracy zostały wykorzystane trzy sposoby wnioskowania statystycznego. Ponadto badanie umiejętności zarządzających przeprowadzono z zastosowaniem dwóch klasycznych narzędzi pozwalających na ocenę właściwego doboru walorów do portfela oraz wyczucia rynku. W tym celu uwzględniono modele Treynora-Mazuya oraz Henrikssona-Mertona, w stosunku do których posłużono się relatywnie długimi szeregami czasowymi dla wielu podmiotów.

Otrzymane rezultaty jedynie częściowo potwierdzają, że zarządzający polskimi funduszami są w stanie dostosować skład portfela do krótkoterminowych trendów na rynku. Jednak wyczucie rynku, mierzone zarówno współczynnikiem $\gamma$, jak i $\theta$, charakteryzuje się ujemnymi wartościami, a zatem zarządzający portfelem nie są w stanie dostarczać dodatkowych korzyści z tytułu wykorzystania ruchów rynkowych. Może to oznaczać, iż ewentualne ponadprzeciętne rezultaty inwestycyjne były możliwe na skutek szczęśliwego zbiegu okoliczności, a nie posiadanych umiejętności zarządzających. W związku z otrzymaniem niejednoznacznych rezultatów, generalnie uzasadnione wydaje się kontynuowanie analiz przy wykorzystaniu innych narzędzi badawczych.

\section{Literatura}

Bhattachary S., Pfleiderer P., 1993, A note on performance evaluation, Technical Report, no. 714, Stanford University.

Borowski K., 2014, Miary umiejętności i wyczucia rynku, Difin, Warszawa.

Connor G., Korajczyk R.A., 1991, The attributes, behavior and performance of U.S. mutual funds, Review of Quantitative Finance and Accounting, vol. 1, s. 2-26. 
Czekaj J., Woś M., Żarnowski J., 2001, Efektywność giełdowego rynku akcji w Polsce. Z perspektywy dziesięciolecia, Wydawnictwo Naukowe PWN, Warszawa.

Dębski W., 2012, Rynek finansowy i jego mechanizmy: podstawy teorii i praktyki, PWN, Warszawa.

Grinblatt M., Titman S., 1989, Mutual fund performance: An analysis of quarterly holdings, Journal of Business, vol. 62, s. 393-416.

Henriksson R.D., Merton R.C., 1981, On market timing and investment performance. II. Statistical procedures for evaluating forecasting skills, Journal of Business, vol. 54, no. 4, s. 513-533.

Homa M., Mościbrodzka M., 2016, Dynamiczne wersje hybrydowych modeli market timing oraz weryfikacja ich przydatności w ocenie ryzyka i efektywności funduszy inwestycyjnych, Finanse, Rynki Finansowe, Ubezpieczenia, nr 1(79), s. 73-85.

Jajuga K., Jajuga T., 2007, Inwestycje. Instrumenty finansowe, aktywa niefinansowe, ryzyko finansowe, inżynieria finansowa, Wydawnictwo Naukowe PWN, Warszawa.

Jensen M., 1968, The performance of mutual funds in the period 1945-1964, Journal of Finance, vol. 23 , no. 2, s. 389-416.

Lintner J., 1965, The valuation of risk assets and the selection of risky investments in stock, portfolios and capital budgets, The Review of Economics and Statistics, vol. 47, no. 1, s. 13-37.

Mossin J., 1966, Equilibrium in a capital asset market, Econometrica, vol. 34, no. 4, s. 768-783.

Miziołek T., Trzebiński A.A., 2017, Efektywność polskich funduszy inwestycyjnych - przeglad metod i literatury, Finanse, nr 1(10), s. 93-119.

Olbryś J., 2010, Ocena efektywności zarządzania portfelem funduszu inwestycyjnego z wykorzystaniem wybranych wieloczynnikowych modeli market-timing, Optimum. Studia Ekonomiczne, nr 4(48), s. 44-61.

Perez K., 2011, Analyzing short-term persistence in Polish mutual funds performance, Advances in Global Management Development, no. 20, s. 157-164.

Perez K., 2012, Efektywność funduszy inwestycyjnych. Podejście techniczne i fundamentalne, Difin, Warszawa.

Pietrzyk R., 2013, Efektywność inwestycji polskich funduszy inwestycyjnych z tytułu doboru papierów wartościowych i umiejętności wykorzystania trendów rynkowych, Prace Naukowe Uniwersytetu Ekonomicznego we Wrocławiu, nr 278, s. 351-361.

Pietrzyk R., 2014, Porównanie metod pomiaru efektywności zarządzania portfelami funduszy inwestycyjnych, Prace Naukowe Uniwersytetu Ekonomicznego we Wrocławiu, nr 328, s. 290-298.

Sharpe W.F., 1964, Capital asset prices: A theory of market equilibrium under conditions of risk, Journal of Finance, vol. 19, no. 3, s. 425-442.

Treynor J., Mazuy K., 1966, Can mutual funds outguess the market?, Harvard Business Review, vol. 44, no. 4, s. 131-136.

Węgrzyn T., 2015, Efektywność funduszy inwestycyjnych stosujących aktywne strategie zarzadzania portfelem, Studia Ekonomiczne, Zeszyty Naukowe Uniwersytetu Ekonomicznego w Katowicach, nr 239, s. 141-152.

Witkowska D., Kompa K., Grabska M., 2009, Badanie informacyjnej efektywności rynku w formie silnej na przykładzie wybranych funduszy inwestycyjnych, Metody Ilościowe w Badaniach Ekonomicznych, nr 10, s. 265-285.

Włodarczyk A., Skrodzka W., 2013, Modelowanie procesów decyzyjnych na rynku funduszy inwestycyjnych $z$ wykorzystaniem przełacznikowego modelu Treynora-Mazuy'ego, Zarządzanie i Finanse, vol. 11, nr 4/4, s. 211-226.

Zamojska A., 2012, Efektywność funduszy inwestycyjnych w Polsce. Studium teoretyczno-empiryczne, C.H. Beck, Warszawa.

Żelazowska I., 2017, Wyczucie rynku w działalności funduszy inwestycyjnych akcji w Polsce - badanie empiryczne, Annales Universitatis Mariae Curie-Skłodowska, sectio H - Oeconomia, vol. 51, nr 1, s. 125-134. 